\section{Aspectos clínicos e epidemiológicos da infecção pelos vírus dengue em áreas endêmicas do Brasil}

Foram realizados inquéritos soroepidemiológicos em escolares dos Municípios de Niterói e Paracambi (RJ). Anticorpos inibidores da hemaglutinação para dengue foram observados em $66 \%(297 / 450)$ e em $39,2 \%(145 / 370)$ dos escolares, respectivamente.

Um estudo sorológico retrospectivo também foi realizado em Fortaleza, Estado do Ceará, com o objetivo de avaliar a atividade dos vírus dengue antes do reconhecimento da epidemia de 1994. As amostras de soro estudadas foram obtidas de pacientes com doença febril exantemática e com sorologia negativa para rubéola. Os resultados demonstraram a atividade dos vírus dengue em Fortaleza, aproximadamente seis meses antes do início da epidemia, reforçando a importância da inclusão do dengue no diagnóstico diferencial das enfermidades febris exantemáticas.

Com o objetivo de identificar possíveis enfermidades crônicas atuando como fatores de risco para o desenvolvimento de dengue hemorrágico $(\mathrm{DH})$, foram realizados dois estudos durante as epidemias ocorridas em Niterói (RJ), em 1990-91 e no Estado do Rio Grande do Norte (RN), em 1997. As freqüências de relatos de hipertensão arterial foram de $51,7 \%$ e de $29 \%$ entre os pacientes estudados em Niterói (RJ) e no RN, respectivamente. $\mathrm{Na}$ população brasileira em geral, a prevalência desta doença é de $15 \pm 3 \%$, demonstrando diferenças estatisticamente significativas. Diabetes mellitus foi relatada por $16,7 \%$ dos pacientes no $\mathrm{RN}$ e por $1,7 \%$ em Niterói. A prevalência média de diabetes mellitus na população brasileira é de $7,6 \%$.

No Estado do Rio Grande do Norte, a epidemia com a co-circulação dos vírus DEN-1 e DEN-2 teve seu pico registrado em maio de 1997 e até a semana epidemiológica 26 foram notificados 18.021 casos. Os sintomas mais freqüentes entre 6.151 pacientes com dengue clássico foram febre $(96,7 \%)$, cefaléia $(92,7 \%)$ e

\section{Epidemiological and clinical aspects of infection by dengue virus in endemic areas of the Brazil}

Seroepidemiological investigations were carried out with schoolchildren in the municipalities of Niterói and Paracambi (RJ). Hemagglutination inhibiting antibodies for dengue were observed in 66\% (297/450) and $39,2 \%(145 / 370)$ of schoolchildren, respectively.

A retrospective serological study was also carried out in Fortaleza, State of Ceará, aiming to evaluate the activity of dengue virus before the recognition of the epidemic of 1994. The studied serum samples were obtained from patients with exanthematic fever and with negative serology for rubeola. The results demonstrated the activity of the dengue virus in Fortaleza approximately six months before the beginning of the epidemic, reinforcing the importance of including dengue in the differential diagnostication of exanthemas.

In order to identify possible chronic infirmities acting as risk factors for the development of dengue haemorrhagic fever (DH) two studies were carried out during the epidemics in Niterói (RJ) in 1990/91 and in the State of Rio Grande do Norte (RN) in 1997. The frequency of reports of arterial hypertension were $51.7 \%$ and $29 \%$ among the patients studied in Niterói (RJ) and in RN, respectively. In the Brazilian population in general, the prevalence of this disease is $15 \pm 3 \%$, demonstrating statistically significant differences. Diabetes mellitus was reported by $16.7 \%$ of patients in $\mathrm{RN}$ and by $1.7 \%$ in Niterói. The mean prevalence of diabetes mellitus in the Brazilian population is $7.6 \%$.

In the State of Rio Grande do Norte the epidemic with co-circulation of virus Den- 1 and Den-2 had its peak registered in May 1997 and to the 26th epidemiological week, 18.021 cases were notified.

The most frequent symptoms among the patients with classic dengue were fever $(96.7 \%)$, headache $(92.7 \%)$ and myalgias $(79.9 \%)$. The principal haemorrhagic manifestations among

Recebido para publicação em 27/02/98. 
mialgias $(79,9 \%)$ e as principais manifestações hemorrágicas entre os 28 casos de $\mathrm{DH}$ foram petéquias e gengivorragias. Manifestações não usuais com envolvimento do sistema nervoso central (SNC) e achados anatomopatológicos também foram descritos. the 28 cases of $\mathrm{DH}$ were petechiae and gum bleeding. Unusual manifestation involving the Central Nervous System (CNS) and anatomopathological findings were also described.

Rivaldo Venâncio da Cunha

Tese apresentada ao Instituto Oswaldo Cruz da

Fundação Oswaldo Cruz, para obtenção

do Título de Doutor.

Rio de Janeiro, RJ, Brasil, 1997 